\title{
A Holocene record of coastal landscape dynamics in the eastern Kimberley region, Australia
}

\author{
ULRIKE PROSKE, ${ }^{1,2 *}$ DAVID HESLOP ${ }^{2}$ and SIMON HABERLE ${ }^{1}$ \\ ${ }^{1}$ Department of Archaeology \& Natural History, Australian National University (ANU), Canberra, ACT 0200, Australia \\ ${ }^{2}$ Department of Research School of Earth Sciences, Australian National University (ANU), Canberra, ACT 0200, Australia \\ Received 5 November 2013; Revised 7 January 2014; Accepted 18 January 2014
}

\begin{abstract}
A 6-m-long sediment core from the King River region of north-west Australia has been analysed using sedimentological and palynological techniques. The core spans most parts of the Holocene and contains a detailed record of early to mid-Holocene landscape development. In the early Holocene an intertidal environment supported a diverse and probably extensive mangrove forest. Intensified fluvial activity, high mangrove biodiversity and the proximity of freshwater swamp vegetation reflect enhanced summer monsoon rainfall. From $7.4 \mathrm{k}$ cal a BP onwards, the mangrove forest starts to contract reaching minimum (and probably present-day) extent by $6.5 \mathrm{k}$ cal a BP. Late Holocene aridification led to shifts in mangrove composition, the expansion of hypersaline flats and the transition of freshwater swamps to intermittent wetlands. In addition, fire potentially played an increasing role in controlling ecosystem composition, in particular in the savanna/woodland vegetation. This record is the first of its kind from coastal north-west Australia and demonstrates that sea-level and climatic fluctuations, in addition to local geomorphological settings, are major controllers of landscape development. Although the general pattern of change is similar to other sites in tropical Australia, detailed analysis shows that the timing and character of vegetation shifts are considerably different. Copyright (C) 2014 John Wiley \& Sons, Ltd.
\end{abstract}

KEYWORDS: coastal development; Holocene; Kimberley; Western Australia; mangrove.

\section{Introduction}

Throughout the Holocene, tropical coastlines have changed profoundly due to postglacial sea-level fluctuations, shifts in climate and geomorphological processes. In tropical northern Australia, sediment records and isostatic modelling show that postglacial sea-level history varies considerably from region to region (Lambeck and Nakada, 1990; Lambeck, 2002; Woodroffe, 2009; Lewis et al., 2013). For example, in the van Diemen Gulf sea-level reached modern level ca. 7.4 \pm $0.2 \mathrm{k}$ cal a BP, whereas regions in the Gulf of Carpentaria and eastern Queensland experienced a mid-Holocene sea-level highstand of several metres above modern level (Lewis et al., 2013). The flooding of previously exposed landscapes created new habitats for mangroves throughout tropical northern Australia, leading, in places, to a large-scale expansion of mangrove forests, referred to as the 'big swamp'-phase (Woodroffe et al., 1985c; Woodroffe, 1988; Crowley, 1996). During the late Holocene, sea-level stabilized at modern levels and geomorphological processes led to a general decline in mangrove habitat and thus to an overall decrease in mangrove forest coverage (Woodroffe et al., 1985c; Woodroffe, 1988; Crowley, 1996; Grindrod et al., 1999, 2002).

In addition to sea-level fluctuations, Holocene climate shifts also affected mangrove forests, in particular regarding their composition and biodiversity (Crowley, 1996; Grindrod et al., 2002). An increase in summer monsoon rainfall during the early Holocene delivered more moisture to northern Australia and culminated in a regionally varied, early to mid-Holocene maximum in effective precipitation (Shulmeister, 1992; Denniston et al., 2013; Reeves et al., 2013). Luxuriant growth and high mangrove biodiversity are observed in humid regions today, which has led to speculations that locally the mid-Holocene precipitation maximum may have facilitated opulent growth of the 'big swamp'phase forests (Jennings, 1975; Grindrod et al., 2002). Late Holocene climate is characterized by a general drying trend

${ }^{*}$ Correspondence: U. Proske, as above.

E-mail: ulrike.proske@anu.edu.au which is ascribed to El Niño-Southern Oscillation (ENSO) variability leading to a weakened and more variable summer monsoon (Denniston et al., 2013; Reeves et al., 2013). In the last millennium, however, the climate-ENSO link appears to become muted in Australia's north-west (Denniston et al., 2013). Over the last approx. 4000 years, mangrove forests have stabilized spatially and compositionally in tropical Australia (Crowley, 1996). In the humid tropics, forests remain highly biodiverse, whereas in the semi-arid regions mangrove diversity declined (Crowley, 1996).

Our knowledge of mangrove forest response to sea-level and climate shifts in Australia is largely based on pollen records from the Northern Territory and Queensland. However, the semi-arid region of tropical Western Australia remains unstudied with palynological methods. The aim of this study is to gain a detailed understanding of regional coastal ecosystem dynamics during the Holocene. We focus on Western Australia's Ord River/Cambridge Gulf region, which hosts extensive and relatively diverse mangroves. We present the first palaeoenvironmental reconstruction for the region based on a combination of palynological and sedimentological techniques.

\section{Regional context}

One-fifth of Australia's mangrove forest is concentrated in the Kimberley region (Duke, 2006). Marine sediment records from the Joseph Bonaparte Gulf (JBG, Fig. 1) imply that postglacial sea-level rise reached modern datum either around 6 or $4.7 \mathrm{k}$ cal a BP (Clarke and Ringis, 2000; Yokoyama et al., 2000; Lewis et al., 2013). Stratigraphic and geomorphological data from the region have been interpreted as indicators of a 1-2-m highstand during the mid-Holocene (Jennings, 1975; Lees, 1992; Lessa and Masselink, 2006). Modelled sea-level reconstructions, however, imply that marine deposits above modern mean sea-level in the Ord River estuary could result from late Holocene hydro-isostatic adjustments rather than a mid-Holocene highstand (Lambeck and Nakada, 1990).

To date, evidence for a mid-Holocene 'big swamp'-phase in the north-west is sparse and consists of poorly preserved 


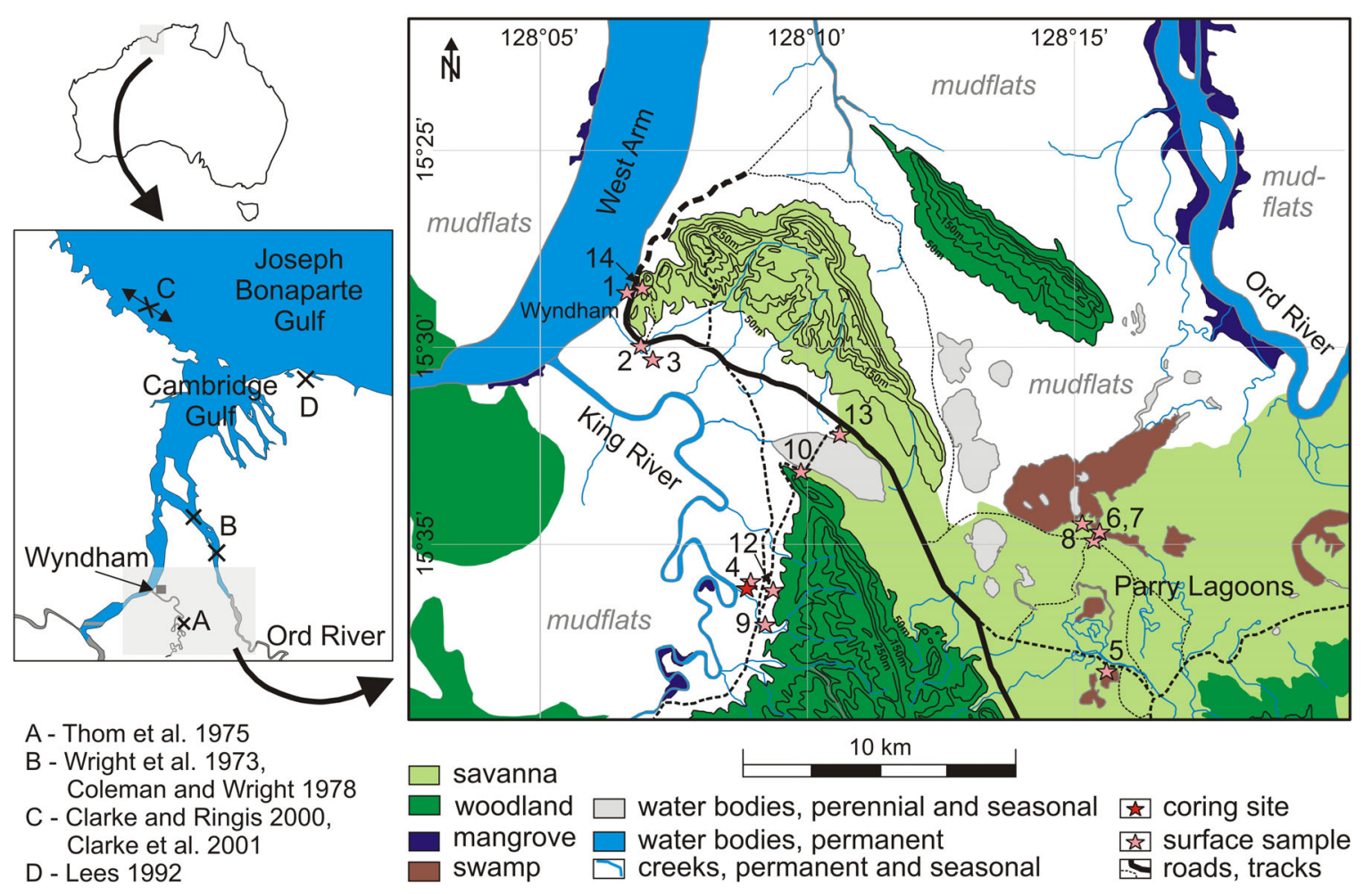

Figure 1. Overview map of the study region. The left-hand panel shows the study area within the regional context and marks sites of previous research (for details see text). The right-hand panel shows the Wyndham region, its major landscape and vegetation units (adapted from Topographic Map of Mt Erskine and Beard, 1979) and the sampling locations for this study. This figure is available in colour online at wileyonlinelibrary.com.

pollen, unspecified 'mangrove muds' and buried mangrove trees (Jennings, 1975; Lees, 1992; Clarke and Ringis, 2000; Clarke et al., 2001). Enhanced summer monsoon rainfall between 7.5 and $4.5 \mathrm{k}$ cal a BP probably supplied more freshwater and sediment to the coast, conditions that may have facilitated widespread mangrove coverage (Denniston et al., 2013). During the late Holocene, a generally drier climate with reduced fluvial activity caused mangrove habitats to contract while riparian and dryland vegetation expanded (van der Kaars et al., 2006; McGowan et al., 2012; Denniston et al., 2013).

Our study area includes Parry Lagoons Nature Reserve and Wyndham $\left(15.4872^{\circ} \mathrm{S}, 128.1247^{\circ} \mathrm{E}, 11 \mathrm{~m}\right.$ a.m.s.l.) which are situated approx. $100 \mathrm{~km}$ north-west of Kununurra (Fig. 1). Wyndham's climate is classified as semi-arid and monsoonal with precipitation ranging between $0 \mathrm{~mm}$ (August, SE monsoon) and approx. $200 \mathrm{~mm}$ month $^{-1}$ (February, NW monsoon) and an average annual rainfall of approx. $820 \mathrm{~mm}$ (Bureau of Meterology, 2011). Much of the annual rainfall is associated with cyclonic depressions and/or tropical cyclones. Mean temperatures vary between $39{ }^{\circ} \mathrm{C}$ (November) and $17^{\circ} \mathrm{C}$ (July) (Bureau of Meterology, 2011). High temperatures and precipitation minima lead to extreme evaporation during the early summer months. The semidiurnal tides in Wyndham can range up to $8.3 \mathrm{~m}$ above the Lowest Astronomical Tide (Bureau of Meterology, 2011).

Discharge and sediment export in the shallow Cambridge Gulf West Arm varies with precipitation, whereas strong tidal currents and occasional river floods control sediment import and deposition (Coleman and Wright, 1978). Sediment export and import appear to be approximately in balance, leading to geomorphological stability in the modern West Arm (Wolanski et al., 2001). Along its approximately 30-km-long course, the King River has a mean tidal amplitude of approximately $3 \mathrm{~m}$ (Coleman and Wright, 1978). Although the King River is highly sinuous, lateral channel migration is very slow (Wright et al., 1973; Coleman and Wright, 1978).

The inland vegetation in the study area can be broadly categorized into four major groups (Beard, 1979): savanna woodland, low tree/short bunch-grass savanna, sparse tree/ high grass savanna and steppe woodland. Saline mudflats are often barren or sparsely vegetated by halophytes, whereas the river-fringing mangroves can consist of up to 14 species per site (Thom et al., 1975; Wells et al., 1985; CALM, 1998, 2008). Generally, Avicennia marina and A. marina subsp. eucalyptifolia are distributed broadly and are only absent from Rhizophora stylosa-dominated forests and Ceriops australis/Excoecaria agallocha thickets (Thom et al., 1975). C. australis appears to thrive in estuarine areas with freshwater seepage, whereas Aegiceras corniculatum grows primarily on river banks subjected to pronounced freshwater input. $R$. stylosa is the only species of Rhizophora recorded for the region and is restricted to the outer part of the Cambridge Gulf-Ord River system (Thom et al., 1975; CALM, 1998; $\mathrm{WAH}, 1998)$. The mangrove association along the King River mainly consists of Avicennia spp. and Ceriops australis with local occurrences of A. corniculatum, Aegialitis annulata, Xylocarpus moluccensis and E. agallocha (Thom et al., 1975; WAH, 1998). Within Western Australia the Cambridge Gulf mangroves are remarkably diverse given that communities in semi-arid environments usually contain only up to eight species per site (Semeniuk, 1983).

\section{Materials and methods}

Core KR02 was taken in 2011 with a 50-cm-long D-sectioncorer at the landward edge of the mangrove swamp in the middle section of the King River at approximately $3 \mathrm{~m}$ a.m.s.I. (Fig. 1, $15^{\circ} 34^{\prime} 13.296^{\prime \prime} \mathrm{S}, 128^{\circ} 8^{\prime} 22.74^{\prime \prime} \mathrm{E}$ ). The core top height relative to sea-level was derived from a topographical map 
(Department of Defence, 2005). The core was described in the field and sampled in the laboratory. To reconstruct efficiency of pollen trapping/dispersal and pollen composition on different substrates outside the mangrove forest, 18 surface samples of approximately $5 \times 5 \times 2 \mathrm{~cm}$ were taken in a variety of local environments (Fig. 1, supplementary Table S1).

\section{Radiocarbon dating}

Six samples of pollen concentrates from core KR02 were radiocarbon dated by accelerator mass spectrometry at the ANU Radiocarbon Dating Laboratory and are listed in Table 1 (Fallon et al., 2010). A probabilistic age-depth model was estimated using the Bayesian approach of Haslett and Parnell (2008), which assumes sedimentation follows a continuous Markov monotone stochastic process. The age-depth model was calculated with the Bchron 3.2 package and the Southern Hemisphere radiocarbon calibration curve (McCormac et al., 2004; Haslett and Parnell, 2008; Parnell et al., 2011).

\section{Grain size analysis}

Samples for grain size analysis were taken every $10 \mathrm{~cm}$ in core KR02 (total of 61 samples) and measured using laser diffraction. All samples were treated with $30 \% \mathrm{H}_{2} \mathrm{O}_{2}$, passed through a 2000- $\mu \mathrm{m}$ sieve, treated with $10 \% \mathrm{HCl}$ and transferred into Calgon $\left(\mathrm{Na}_{6} \mathrm{O}_{18} \mathrm{P}_{6}\right)$. In addition, every sample was physically dispersed using ultrasound for 30 seconds (Ryżak and Bieganowski, 2011). All samples were measured five times using the Malvern Mastersizer 2000 with Hydro MU attachment at the the Fenner School of Environment \& Society at ANU. The average spectrum of these five repeat measurements for each sample was used to represent the grain size distribution.

Characteristic statistics (sorting, skewness, etc.) were calculated based on the geometric method of moments using the GRADISTAT package (Blott and Pye, 2001). Furthermore, the grain size spectra were analysed using an end-member modelling algorithm (Weltje, 1997). This approach assumes that particle assemblages are produced through the combination of a small number of fixed end-members. The geometric method of Weltje (1997) allows the simultaneous estimation of the end-member grain size spectra and the proportions in which they must be mixed together to reproduce the measured sample data set. In this way the grain size data can be placed into a single empirical framework that forms the basis for consistent sample comparisons.

\section{Pollen, spore and charcoal analysis}

Processing for pollen analysis was carried out on 38 samples from KRO2 and all surface samples following the standard $\mathrm{KOH}, \mathrm{HF}, \mathrm{HCl}$ and acetolysis method (Bennett and Willis, 2001). Sample residues were mounted on slides and a minimum of 250-300 pollen grains were counted per sample

Table 1. Radiocarbon ages for core KR02.

\begin{tabular}{lccc}
\hline $\begin{array}{l}\text { Sample } \\
\text { depth }(\mathrm{cm})\end{array}$ & $\begin{array}{c}\text { Uncalibrated }{ }^{14} \mathrm{C} \\
\text { age }\end{array}$ & $\begin{array}{c}\text { Calibrated age } \\
(95 \%)(\text { cal a BP })\end{array}$ & Labcode \\
\hline $21-24$ & $1830 \pm 10$ & $1620-1790$ & ANU 35405 \\
$113-116$ & $6500 \pm 35$ & $7280-7430$ & ANU 35406 \\
$155-157$ & $6550 \pm 45$ & $7300-7500$ & ANU 31709 \\
$291-293$ & $6610 \pm 60$ & $7330-7560$ & ANU 32712 \\
$375-377$ & $7470 \pm 110$ & $8010-8400$ & ANU 32713 \\
$579-581$ & $6900 \pm 60$ & $7590-7820$ & ANU 33413 \\
\hline
\end{tabular}

(400× magnification). Pollen identification and nomenclature follows that set out in earlier reference publications (Huang, 1972; Thanikaimoni, 1987; Mao et al., 2012) and regional reference collections held at the Department of Archaeology and Natural History, ANU (online collection at apsa.anu.edu. $\mathrm{au} /$ ). Pollen taxa are divided into the following ecological groups: mangrove (including all core mangrove taxa and fringing back mangroves, such as Excoecaria spp. and Batis spp.), tidal flat and salt marsh (Aizoaceae, Chenopodiaceae/ Amaranthaceae, Gomphrena spp.), riverine/freshwater areas (e.g. Gonocarpus spp., Cyperaceae, Nymphoides spp., Pandanus spp.), woodland and savanna (e.g. Proteacae, Cochlospermum spp., Dodonaea spp., Myrtaceae), Poaceae and Cyperaceae. These ecological groups are adapted from the Lower Ord RAMSAR site report (CALM, 1998) and FloraBase (WAH, 1998). Pollen counts are expressed as percentages of the total pollen sum (excluding pteridophyte spores and aquatic vascular plant pollen). Results were analysed and plotted using psimpoll (Bennett, 2005). As the counted pollen assemblage is only a sample of the total population, the uncertainty associated with each taxon's relative abundance must be estimated. To establish this uncertainty, minimum and maximum percentage values of the major taxa (which account for at least $5 \%$ of total pollen in at least one sample) were calculated at the $\alpha=0.05$ significance level (Heslop et al., 2011).

Charcoal particles on the pollen slides (micro-charcoal $<125 \mu \mathrm{m}$ : black, opaque angular particles $>10 \mu \mathrm{m})$ were counted as an indicator of fire in the landscape (Whitlock and Larsen, 2001). Six hundred samples from core KR02 were sub-sampled $\left(0.5-1 \mathrm{~cm}^{3}\right)$ for macro-charcoal analysis (Stevenson and Haberle, 2005). The concentrations of charcoal fragments were counted under a Zeiss stereo microscope at $100 \times$ magnification.

\section{Results}

\section{Pollen, spore and charcoal analysis of surface samples}

Of the 18 collected surface sediment samples, only 13 yielded sufficient pollen to be included in the analysis (Figs 1 and 2, Table S1). Pollen were grouped into ecological units following the approach outlined above. Mangrove pollen taxa are only present in samples taken closest to the King River and Cambridge Gulf West Arm (samples 1-3 and 14). The pollen assemblage in most samples is dominated by the regional vegetation communities and only two samples (samples 7 and 13) record the immediate vegetation reasonably well. Notably, adjacent samples 6 and 7 contain very different assemblages, with the former dominated by Poaceae and the latter a mix of Poaceae, Cyperaceae, riverine/ freshwater and tidal flat/salt marsh taxa. Despite these inconsistencies, pollen export can be assessed and transport distances broadly estimated (Table 2). These export values are then used to infer the proximity of different vegetation communities to the KR02 site throughout the Holocene.

In this environment the substrate appears to play only a minor role in controlling the effectiveness of pollen trapping. Tidal flat samples exhibit only slightly lower pollen concentration values than samples taken from standing water bodies (Fig. 2). Spore concentrations are considered less meaningful as ferns are often absent from the landscape and overland spore transport appears to be limited. Microcharcoal concentrations indicate that perennial and intermittent water bodies, as well as tidal flats, trap microcharcoal less effectively than substrates that are only submerged occasionally. 


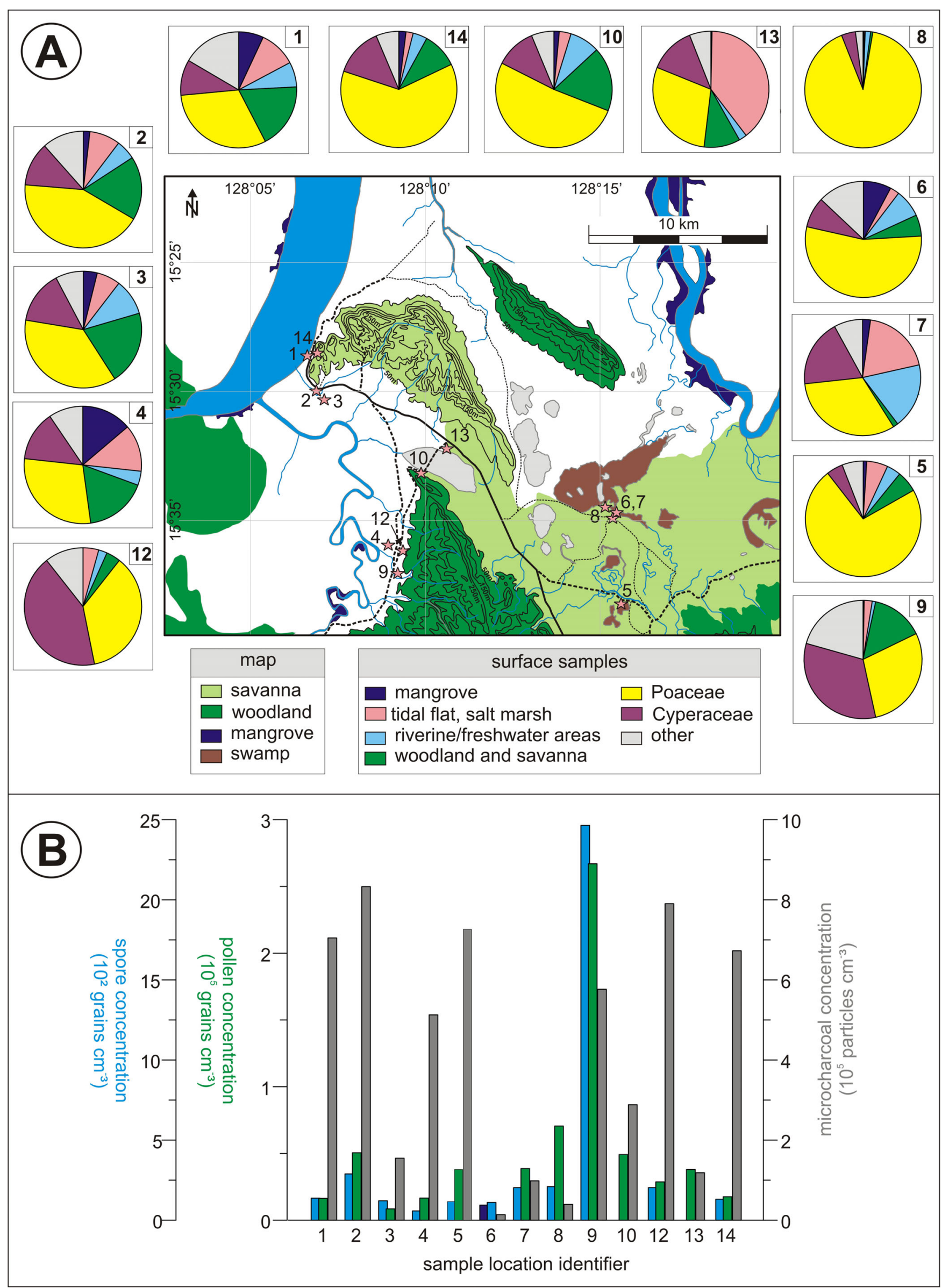

Figure 2. Palynological and microcharcoal data of surface sediment samples. Individual sample numbers are given in the top right-hand corner of each plot. Detailed information on each sampling site including numerical values for each vegetation group can be found in Table S1. This figure is available in colour online at wileyonlinelibrary.com. 
Table 2. Estimates of pollen export for selected taxa. Values are based on palynological results from all surface sediment samples.

\begin{tabular}{|c|c|c|c|}
\hline Vegetation community & $\begin{array}{l}\text { Commonly observed and } \\
\text { indicative taxon }\end{array}$ & Pollination vector* & Pollen export estimates ${ }^{\dagger}$ \\
\hline \multirow[t]{6}{*}{ Mangrove } & Rhizophora spp. & Wind & 1-10\%: approx. $250 \mathrm{~m} ;>10 \%$ : approx. $50 \mathrm{~m}$ \\
\hline & Xylocarpus spp. & Insects & $1-2 \%:$ approx. $250 \mathrm{~m}$ \\
\hline & Aegiceras corniculatum & Insects & 1\%: approx. 250 m \\
\hline & Avicennia spp. & Insects & 1\%: approx. $100 \mathrm{~m}$ \\
\hline & Bruguiera spp. & Birds & \\
\hline & Ceriops spp. & Insects & \\
\hline \multirow[t]{2}{*}{ Fringing back mangrove } & Batis spp. & Animals & \\
\hline & Excoecaria spp. & Insects & $1-10 \%$ : approx. $50 \mathrm{~m}^{\ddagger}$ \\
\hline \multirow[t]{3}{*}{ Tidal flat, salt marsh } & Sesuvium portulacastrum & Insects & $1-5 \%:$ approx. $100 \mathrm{~m}$ \\
\hline & Chenopodiaceae/Amaranthaceae & Wind, insects & 1-10\%: approx. $50 \mathrm{~m} ;>10 \%$ : approx. $10 \mathrm{~m}$ \\
\hline & Gomphrena spp. & Wind, insects & $1-10 \%$ : approx. $400 \mathrm{~m} ;>10 \%$ : approx. $50 \mathrm{~m}$ \\
\hline \multirow[t]{3}{*}{ Riverine/freshwater areas } & Gonocarpus spp. & Wind & $1-3 \%:$ approx. $350 \mathrm{~m}$ \\
\hline & Pandanus spp. & Wind, insects & 1\%: approx. $400 \mathrm{~m}$ \\
\hline & Hygrophila angustifolia & Insects & 1-2\%: approx. $500 \mathrm{~m}$ \\
\hline \multirow[t]{3}{*}{ Woodland and savanna } & Trema spp. and Celtis spp. & Insects & 1\%: approx. 500-1000 m \\
\hline & Dodonaea spp. & Wind & $1 \%$ : approx. $1000 \mathrm{~m} ;>1 \%$ : approx. $10 \mathrm{~m}$ \\
\hline & Cochlospermum fraseri & Wind & $1 \%$ : са. $500 \mathrm{~m}$ \\
\hline
\end{tabular}

*Source: Tomlinson (1994), WAH (1988-). 'Proportion taxon to total pollen sum, in [m] of respective community. ${ }^{\ddagger}$ Pollen of freshwater tree E. parviflora cannot be distinguished from E. agallocha, and attribution of Excoecaria spp. is therefore problematic.

\section{Radiocarbon age model of core KRO2}

KR02 spans the last ca. $9 \mathrm{ka}$, but most of the core covers the early to mid-Holocene (Fig. 3; Table 1). The sediment between approximately 110 and $30 \mathrm{~cm}$ contains insufficient pollen for dating. In the following, mean ages will be reported. Sedimentation rates (uncorrected for compaction) are very high during the early and mid-Holocene with an average of $3-11 \mathrm{~mm} \mathrm{a}^{-1}$ (until ca. $7.3 \mathrm{k}$ cal a BP). These sedimentation values are typical for mangrove systems, which usually deposit $2-10 \mathrm{~mm} \mathrm{a}^{-1}$ (Ellison, 2008). Subsequently the accumulation rate decreases to an average of $4 \mathrm{~mm} \mathrm{a}^{-1}$ and from $6.5 \mathrm{k}$ cal a BP onwards to $0.2 \mathrm{~mm} \mathrm{a}^{-1}$ (Fig. 3). The pronounced shifts in accumulation rate throughout the early Holocene are at least partially due to the discrete nature of the radiocarbon sampling and cannot be taken as an indicator for sudden environmental change (Fig. 3).

\section{Grain size analysis of core KRO2}

The sediment of core KRO2 consists of fine to medium silt with an average grain size between 8 and $14 \mu \mathrm{m}$ (Fig. 3). Across all samples, clay- and sand-sized particles contribute $<10 \%$ each to the grain size distribution. Sand-sized particles between core depths of 0 and $200 \mathrm{~cm}$ are most likely nodules of iron(hydr)oxides that formed during post-depositional soil formation processes. Grain size analysis of all samples shows that the sediment is poorly to very poorly sorted, implying a short transport from source to sink. Outcrops of sandstone and shale near the site are the most likely sediment sources. Regarding kurtosis, most of the sediment samples fall within the meso- and leptokurtic range, implying that the grain size distribution is either log-normally distributed or thinner than expected for a log-normal distribution. Further, most of the sediment is either symmetrical or skewed towards the coarser fractions of the grain size spectrum. However, no systematic trend in skewness can be detected, indicating that sediment transport processes have not changed substantially.

In the interval $440-280 \mathrm{~cm}$ a pronounced shift towards coarse silt (approx. 10-20\%) and fine sand (approx. 5-10\%) is observed. Simultaneously, the proportion of grain size endmember 3 (EM 3) increases (Fig. 3). The end-member analysis revealed that EM 3 reflects a bimodal grain size distribution with a modal grain size of approximately $26 \mu \mathrm{m}$ (data not shown). Coarse sediments are primarily transported as bed load or by high-energy river flow (Coleman and Wright, 1978); thus, EM 3 is interpreted as 'bed load/high-energy fluvial input'. Furthermore, samples from 270 to $220 \mathrm{~cm}$ contain euryhaline foraminifera that were identified as species of the genera Elphidium and Massilina (Clarke et al., 2001).

\section{Pollen, spore and charcoal analysis of core KRO2}

Psimpoll identified five distinctive zones in the pollen record (Figs. 4 and 5), which are labelled KR-1 (deepest) to KR-5 (shallowest). Ages for these zones have been derived from the age-depth model and have been rounded to the nearest century. None of the samples in zone KR-4 $(96-32 \mathrm{~cm}$; ca. $6.3-2.4 \mathrm{k}$ cal a BP) yielded any pollen and all yielded only very low charcoal counts. The abundance of iron oxide mottles in this part of the core suggests that the organic material, including charcoal, was consumed by strong acid sulphate soil formation processes (Jaffé et al., 2013).

In the following, percentage values given in parentheses are minimum and maximum values that have been calculated using the method outlined by Heslop et al. (2011).

Two different types of Rhizophora pollen have been observed in KR02: Rhizophora type apiculata/lamarckii and Rhizophora type stylosa/mucronata. Pollen of the former type is characterized by a pronounced equatorially elongated endoaperture and a thick wall that is distinctly stratified (Mao et al., 2012). The latter type exhibits a thinner wall that is less distinctly stratified and a 'bow tie'-like aperture (Mao et al., 2012).

\section{KR-1: $600-490 \mathrm{~cm}$, ca. $9.2-8.6 \mathrm{k} \mathrm{cal} \mathrm{a} \mathrm{BP}$}

The lowermost zone of the record is dominated by mangroves (63-78\%) with Rhizophora type apiculata/lamarckii (14-55\%) being the major taxon, but gradually declining upwards. Besides other Rhizophora-types, mangrove elements such as Avicennia (0-18\%), Bruguiera, Sonneratia, Ceriops and Aegiceras (all $\leq 4 \%$ ) are also present. Outside the 


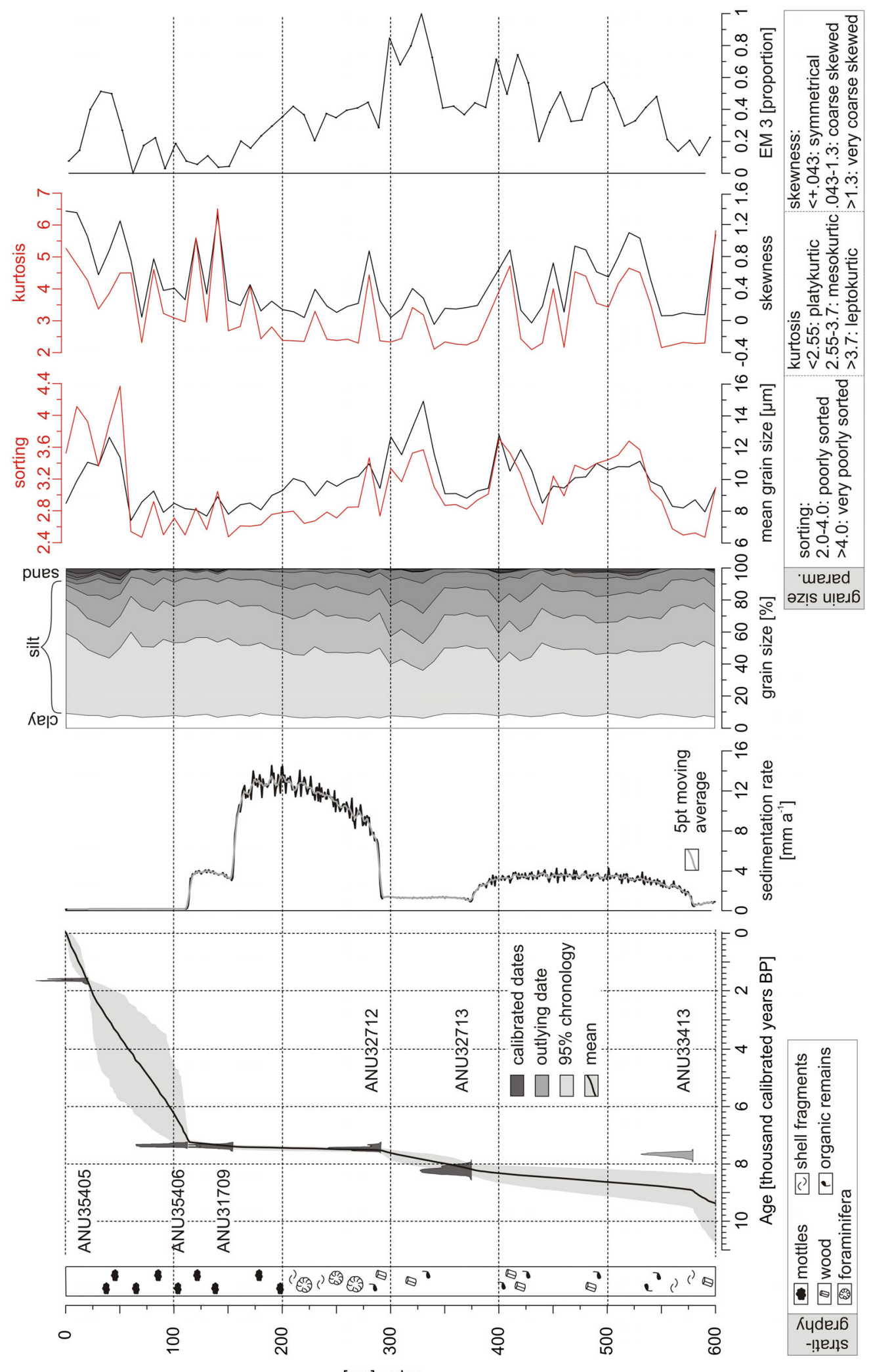

Figure 3. Stratigraphy, age-depth model and sediment parameters for core KR02. The model indicates that it is highly probable that the date for sample ANU33413 is an outlier and its influence has been down-weighted. This figure is available in colour online at wileyonlinelibrary.com.

mangrove community, Fabaceae (1-24\%) and Poaceae $(0.5-20 \%)$ dominate. Furthermore, Myrtaceae, Cyperaceae, Proteaceae and Cochlospermum (all $\leq 5 \%$ ) are represented. Capparis, Dodonaea, Terminalia, Bauhinia and Chenopodiaceae/ Amaranthaceae occur in low abundances (all $\leq 2 \%$ ). Spore accumulation values show an increase to relatively high values, with Doryopteris, Cheilanthes and Ophioglossum being most abundant in this zone.

\section{KR-2: $490-150 \mathrm{~cm}, \mathrm{ca} .8 .6-7.4 \mathrm{k} \mathrm{cal} \mathrm{a} \mathrm{BP}$}

Zone KR-2 continues with a high mangrove pollen percentage (59-78\%) but now with Rhizophora type stylosa/mucronata (11-59\%) dominating. Avicennia (0-27\%), Aegiceras (0-20\%) and Ceriops (0-17\%) abundances are higher than in KR-1, particularly in the uppermost parts of KR-2, whereas values of Sonneratia and Bruguiera $(\leq 3 \%)$ are similar or lower than 


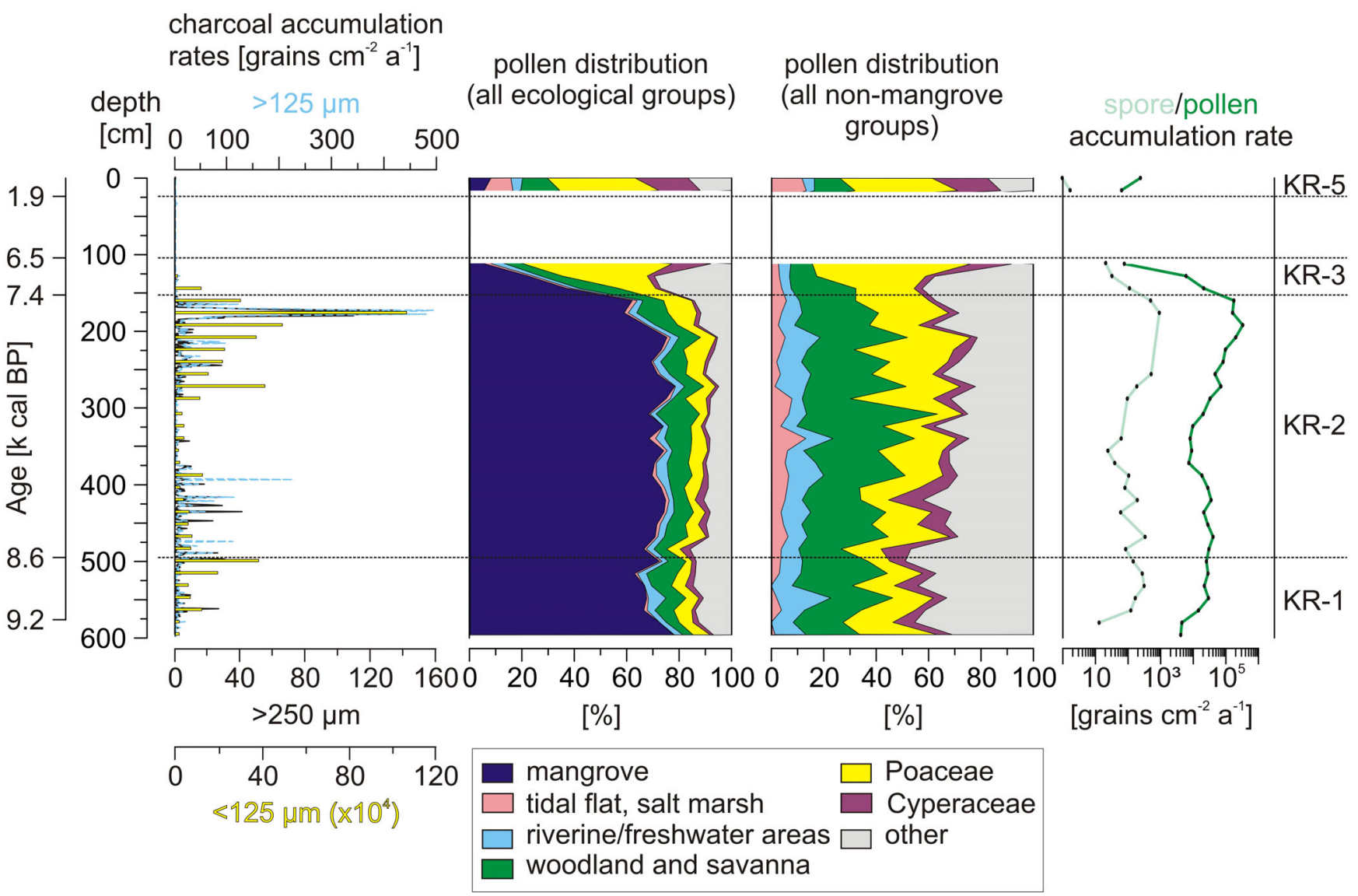

Figure 4. Palynological summary of core KR02. This figure is available in colour online at wileyonlinelibrary.com.

in KR-1. Xylocarpus appears for the first time and Camptostemon occurs irregularly throughout KR-2 (both $\leq 1 \%$ ). Poaceae (0.5-25\%), Fabaceae (0-23\%), Cochlospermum and Myrtaceae (both 0-22\%), Capparis and Cyperaceae (both $\leq 4 \%$ ) together with Terminalia, Chenopodiaceae/Amaranthaceae, Celtis, Trema and Acanthaceae (all $\leq 2 \%$ ) characterize the non-mangrove signal. Spore accumulation values remain relatively high with Cheilanthes, Ophioglossum and Selaginella being prominent throughout KR-2.

\section{KR-3: $150-100 \mathrm{~cm}, 7.4-6.5 \mathrm{k} \mathrm{cal} \mathrm{a} \mathrm{BP}$}

Zone KR-3 shows a shift from mangrove-dominated (37-6\%) to open woodland and savanna vegetation (26-58\%). Rhizophora type stylosa/mucronata (0-21\%), Rhizophora type apiculata/lamarckii (0-22\%), Bruguiera $(\leq 4 \%)$, and Camptostemon and Xylocarpus (both $\leq 2 \%$ ) remain present but decline rapidly towards the top of KR-3. Avicennia (1-32\%) reaches its highest values in the entire core. Poaceae (6-74\%), Fabaceae (0-38\%), Cyperaceae (0-34\%) and Cochlospermum (0-21\%) dominate the non-mangrove signal. Minor occurrences include Myrtaceae, Pandanus and Capparis (all $\leq 4 \%$ ), Chenopodiaceae/Amaranthaceae, Terminalia, Batis and Sesuvium/Aizoaceae (all $\leq 2 \%$ ). Spore accumulation values, reflecting the presence of Acrostichum, Cyclosorus and Ophioglossum, rapidly decline upwards in KR-3.

\section{KR-5: 25-0 cm, 1.9k cal a BP to present}

The uppermost zone is characterized by a continuing dominance of Poaceae (19-61\%), Cyperaceae (5-39\%), Myrtaceae (3-38\%) and Fabaceae (0-23\%). Chenopodiaceae/ Amaranthaceae (1-32\%), Batis, Terminalia, Sesuvium/ Aizoaceae, Gonocarpus and Gomphrena (all $\leq 3 \%$ ) all increase in abundance while mangrove taxa remain minor components $(\leq 5 \%)$. Spore accumulation values are low in the uppermost part of the core with Cyclosorus, Polypodiaceae and Lygodium dominating the signal.

To test if the non-mangrove pollen signal in the sediment core is similar to any of the environmental settings represented by the modern surface samples, the datasets were compared using hierarchical cluster analysis. All vegetation groups, except for 'mangrove', were selected in both the surface and the core sample set. In the core samples the sum of all 'non-mangrove' pollen groups ranges between $96 \%$ $(16 \mathrm{~cm})$ and $22 \%(272 \mathrm{~cm})$, but lies between 25 and 35\% in most samples. Cluster analysis reveals two main groupings in the data (Fig. 6): Cluster 1 contains only core samples while Cluster 2 contains all the surface samples and three KRO2 samples. Cluster analysis reveals that around $7.2 \mathrm{k}$ cal a BP $(112 \mathrm{~cm})$ the non-mangrove vegetation reflects a tidal flat environment with fringing grasses and sedges. A similar signal is recorded for ca. $1.3 \mathrm{k}$ cal a BP $(16 \mathrm{~cm})$ : a tidal flat environment with a strong signal from sedges, grasses and Myrtaceae. The non-mangrove vegetation signature below $112 \mathrm{~cm}$ is not reflected in any of the collected surface samples.

\section{Discussion}

The pollen assemblage of KR02 shows that during the early Holocene a mangrove forest grew at the site with Rhizophora type apiculata/lamarckii dominating the pollen signal (Fig. 5). This forest was established in the area before $9.0 \mathrm{k}$ cal a BP, which is earlier than postulated by Thom et al. (1975). Both $R$. apiculata and $R$. lamarckii thrive in mid-intertidal and intermediate estuarine environments (Duke, 2006). Around $8.6 \mathrm{k}$ cal a BP, Rhizophora type stylosa/mucronata becomes 


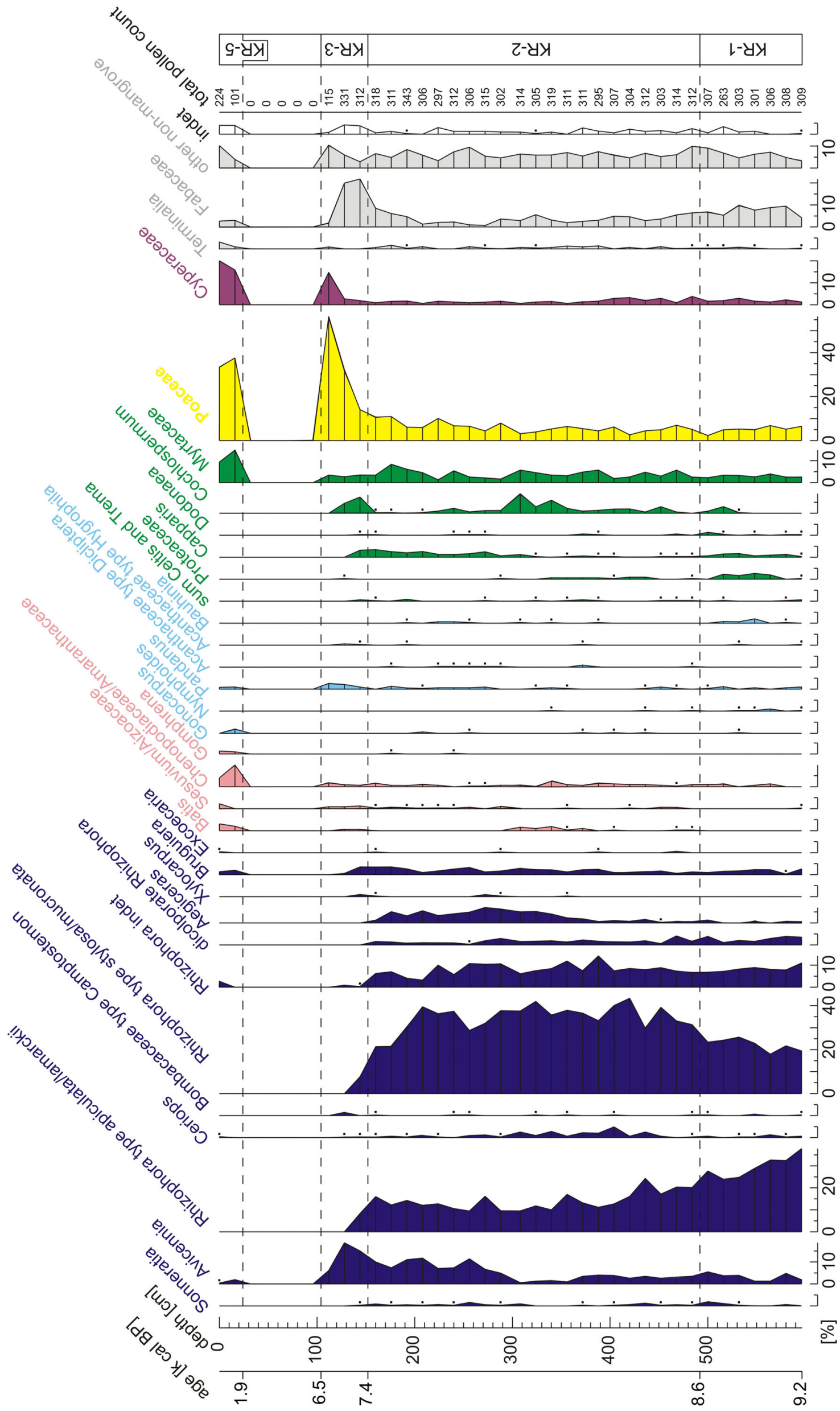

Figure 5. Detailed pollen diagram of KR02 showing all major taxa. Taxa have been colour-coded based on the respective vegetation community (see also Figs 2 and 4). This figure is available in colour online at wileyonlinelibrary.com. 


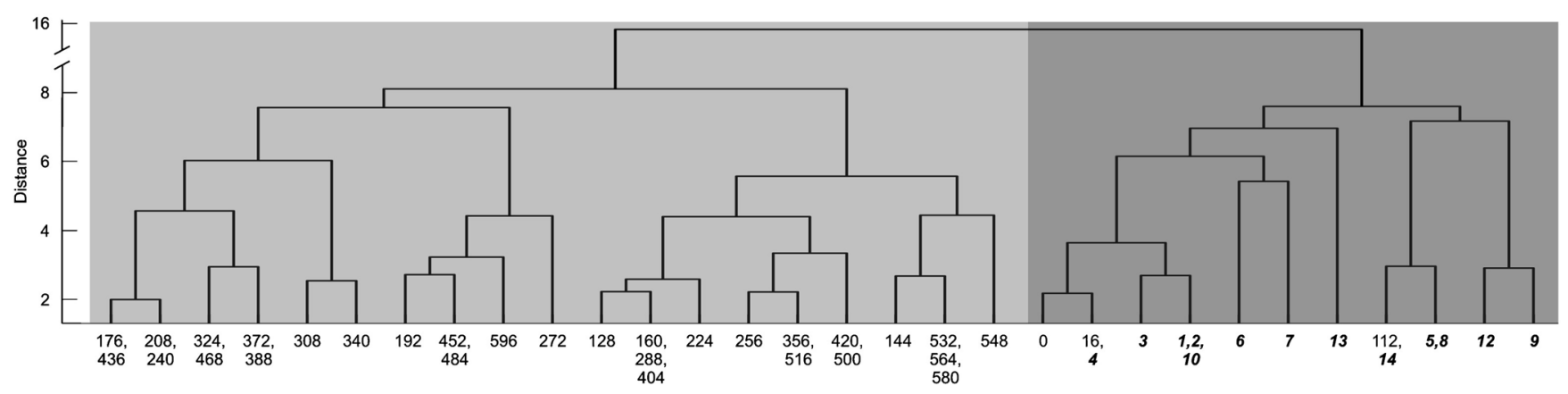

Figure 6. Results of cluster analysis of all surface and sediment core samples. Two clusters were calculated with cluster 1 (lighter grey box) containing most sediment core samples and cluster 2 (darker grey box) containing all surface sediment samples (marked in bold and cursive) and three sediment core samples.

the major taxon in the sequence. Both species grow in a midto low intertidal and downstream/marine position in estuaries (Duke, 2006). This shift implies that after ca. 8.6k cal a BP, postglacial sea-level rise led to a more frequent inundation of the area, which also created new habitat for mangrove colonization (Grindrod et al., 2002; Lewis et al., 2013). Such mangrove forest encroachment during the transgressive stage $(>7.0 \mathrm{k}$ cal a BP) has been reported from numerous sites in tropical northern Australia, such as the Northern Territory's Adelaide, Daly, Alligator and Mary Rivers, Queensland's Mulgrave and Russel Rivers, Missionary Bay and Torres Strait Islands (Crowley, 1996; Woodroffe, 2000; Grindrod et al., 2002; Rowe, 2005). Around ca. 7.5k cal a BP, a small number of foraminifera (Massilina and Elphidium) are recorded in the samples. Massilina spp. is not common in mangrove settings, implying that these tests may have been imported from more open marine settings (Clarke et al., 2001). Elphidium spp. has been recorded from Ceriopsdominated and fine-grained tidal flat sediments, which underlines the tidal character of the sediments from that period (Michie, 1987; Clarke et al., 2001; Wang and Chappell, 2001; Berkeley et al., 2009).

Furthermore, the palynological record reflects enhanced moisture availability in the early Holocene landscape, as has been documented in several records in the greater region (Denniston et al., 2013; Reeves et al., 2013). In the woodland and savanna community, Proteaceae reach peak values between ca. 9.2 and $8.7 \mathrm{k} \mathrm{cal} \mathrm{a} \mathrm{BP.} \mathrm{Plants} \mathrm{in} \mathrm{this} \mathrm{family} \mathrm{grow}$ most prolifically in regions of relatively high and nonseasonal rainfall and are believed to be restricted to a few surviving Hakea and Grevillea species in today's semi-arid regions of Australia (Myerscough et al., 2001). Furthermore, a brief phase of general woodland and savanna expansion between 7.4 and $6.5 \mathrm{k}$ cal a BP is recorded (Fig. 5). In this period, the soil-moisture-dependent Cochlospermum (most likely $C$. fraseri) reaches peak values, which probably reflects enhanced freshwater availability.

In the mangrove forest, at least two different species of Rhizophora are recorded: Rhizophora type apiculatal lamarckii and Rhizophora type stylosa/mucronata. The ecological preferences of these Rhizophora species imply enhanced freshwater availability and longer freshwater retention times (Duke, 2006). Supporting evidence for increased freshwater supply is provided by peaks in grain size EM 3, which implies strongest fluvial activity between ca. 8.4 and $7.5 \mathrm{k}$ cal a BP. Coinciding with this fluvial activity, Aegiceras (probably A. corniculatum, the river mangrove) reaches values $>5 \%$ of the total pollen sum. In mangrove communities, where $A$. corniculatum represents $<50 \%$ of the stand, pollen of the plant are usually poorly represented due to low production (Grindrod, 1988; Somboon, 1990; Crowley et al., 1994; Mao et al., 2006; Li et al., 2008). Therefore, pollen values $>5 \%$ indicate that stands of $A$. corniculatum grew in the immediate vicinity of the site between ca. 8.2 and $7.4 \mathrm{k}$ cal a BP and thus water salinity in the area probably never exceeded ca. $0.5 \%$ over longer periods during that time span (Ball, 1988).

After $7.4 \mathrm{k}$ cal a BP a shift towards a high tide/shallow water environment with decreasing freshwater influence is implied by several observations: the rapid decline of $A$. corniculatum, an increase in back mangrove taxa (Avicennia, Camptostemon, Bruguiera and Xylocarpus), and the decrease in EM 3 and mean grain size. Synchronous substrate salinification is reflected in an increase in tidal/saline flat vegetation and halophytes. Sea-level stabilization together with ongoing vertical sedimentation is the likely explanation for this shift (Lewis et al., 2013) and our observations do not support Thom et al.'s (1975) hypothesis of an extended mangrove forest along the King River until ca. $6 \mathrm{k}$ cal a BP.

By ca. $6.5 \mathrm{k} \mathrm{cal}$ a BP the mangrove forest in the region seems to have been reduced to its present-day coverage, being restricted to narrow fringes along the major permanent streams.

Synchronous with or after forest contraction, mangrove diversity along the King River declined. Today only $R$. stylosa is present in the area but is restricted to the outer parts of the Cambridge Gulf (Wells et al., 1985; CALM, 2008). R. stylosa is tolerant to seasonal changes in environmental parameters, such as salinity, and thus is well adapted to more variable and/or arid conditions (Duke, 2006). Other mangrove forest components, such as Camptostemon schultzii and Bruguiera spp., became limited to positions along the Ord River where freshwater supply appears to be more permanent. This vegetation shift is likely to have been caused by a more variable and temporarily slightly reduced summer monsoon in the mid-Holocene in north-west Australia (McGowan et al., 2012; Denniston et al., 2013).

The early and mid-Holocene mangrove history presented here differs from what has been reported as the 'big swamp'phase during sea-level stabilization at other sites in northern Australia (Grindrod and Rhodes, 1984; Woodroffe et al., 1985a,b; Clark and Guppy, 1988; Crowley et al., 1990; Chappell, 1993; Woodroffe, 1993; Crowley and Gagan, 1995; Crowley, 1996; Mulrennan and Woodroffe, 1998; Rowe, 2005, 2007; Lewis et al., 2013). To compare the timing of vegetation shifts in KR02 with those observed at other 'big swamp'-phase locations, the uncalibrated radiocarbon ages published for the respective sites have been calibrated using the same calibration method as for KRO2 (Table 3). On the basis of these existing chronologies we can infer that the King River mangrove sediments are among the oldest deposits of Holocene mangroves in northern Australia. However, unlike other locations in northern Australia, the 
Table 3. Newly calibrated radiocarbon ages from locations with 'big swamp' deposits in northern Australia.

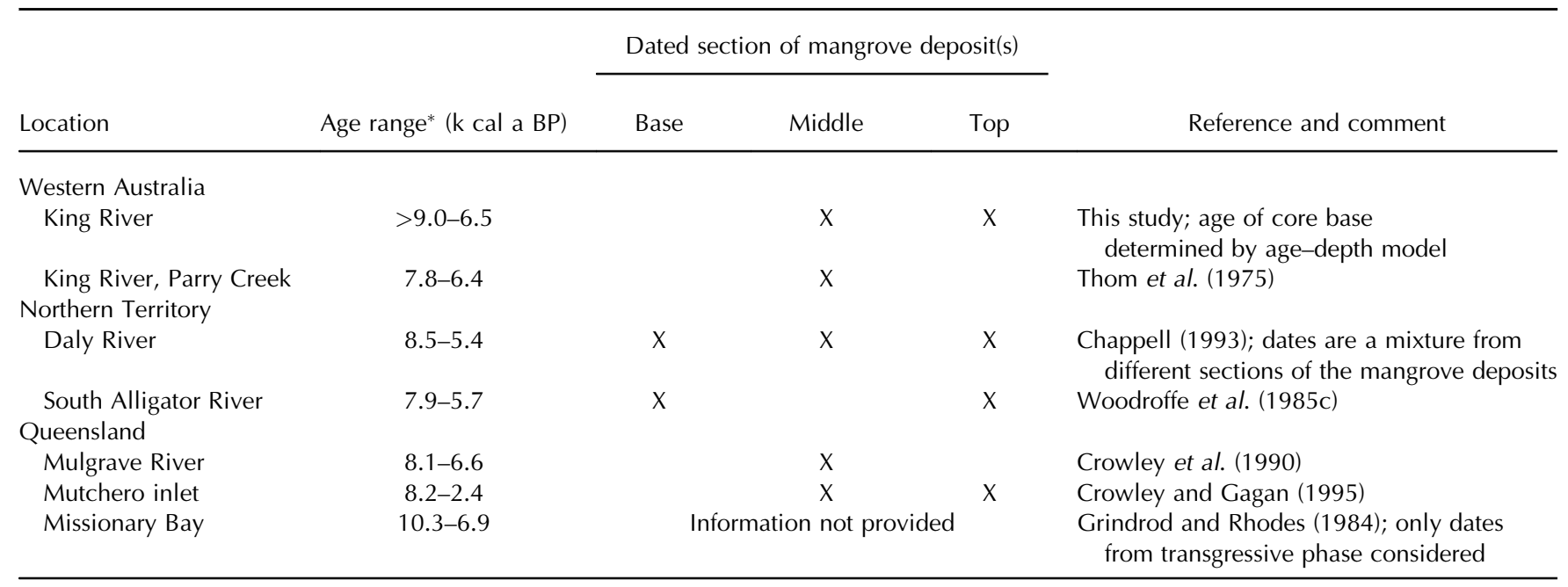

* Radiocarbon age brackets for each study are defined by the youngest and oldest calibrated radiocarbon age.

'big swamp'-phase did not extend into the later parts of the mid-Holocene at our site. Potential mechanisms responsible for this timing offset may be variations in climatic conditions, sea-level history, accommodation space, availability of habitat and/or sediment supply.

Around $4.2 \mathrm{k}$ cal a BP, climate in north-west Australia and the wider region shifted towards drier conditions, reaching peak aridity around $1.5 \mathrm{k}$ cal a BP (Abram et al., 2009; Griffiths et al., 2010; McGowan et al., 2012; Denniston et al., 2013). A lack of palynological evidence between ca. 6.5 and $1.9 \mathrm{k}$ cal a BP prohibits the analysis of local vegetation response to this shift. Thom et al. (1975) speculate that the last roughly 5000 years are characterized by the vertical accretion of tidal flats, contraction/dieback of mangroves and extension of tidal flats under constant sea-level. After $1.9 \mathrm{k}$ cal a BP our record indicates a continued expansion of tidal flat vegetation and a spatial decrease in freshwater seepage areas. Since at least $1.3 \mathrm{k}$ cal a BP, tidal flat vegetation has grown within approximately $10 \mathrm{~m}$ of the site and the presence of Gomphrena implies enhanced vegetation disturbance within approximately $400 \mathrm{~m}$ of the site. Furthermore, permanent freshwater features continue to dry out and become intermittent wetlands characterized by Pandanus and Gonocarpus. This late Holocene expansion of hypersaline flats and the contraction of permanently wet freshwater swamps parallels the 'freshwater'- or 'sinuous/ cuspate'-phase recognized elsewhere in northern Australia (Clark and Guppy, 1988; Woodroffe, 1993, 2000; Crowley, 1996). In this phase, mangrove vegetation has been replaced by saline mudflats in semi-arid regions or wet floodplain vegetation in the wet-dry tropics (Woodroffe and Grindrod, 1991; Woodroffe, 1993, 2000).

\section{The role of fire}

The modern vegetation composition of northern Australia's tropics is affected profoundly by fire (Bowman et al., 2010). Charcoal accumulation rates across all size classes show that fire was present in the landscape throughout the KR02 record, with peaks around ca. 8.4-8.3 and 7.5-7.4k cal a BP (Fig. 4). As both major charcoal accumulation peaks coincide with shifts in local vegetation and sedimentation rate, these are most probably caused by taphonomic processes rather than increased fire activity. This phenomenon of high charcoal accumulation paralleling major vegetation shifts has been observed throughout tropical Australian landscapes and appears to have been most prominent during the early Holocene (Kershaw et al., 2002). Nevertheless, several taxa recorded in KR02 are sensitive to increased fire frequency and may indicate a changing fire regime during the late Holocene. For example, since the mid-Holocene Capparis and Bauhinia are absent from the record, which is potentially due to intense and/or frequent fires (Dyer, 2001; Crowley et al., 2007).

\section{Conclusions}

Results from the palynological and sedimentological analyses of sediment core KR02, south-east of Wyndham, show that during the early Holocene the region was characterized by an intertidal environment that supported a diverse and probably extensive mangrove forest. Multiple indicators show that more freshwater was available in the landscape during this phase. Newly calibrated radiocarbon ages from other northern Australian 'big swamp' sites together with the evidence presented here demonstrate that mangrove deposits along the King River are among the oldest in northern Australia and that the 'big swamp' phase may have terminated earlier than at the other sites. Based on our results we find no evidence for a higher than present sea-level during this phase. The late Holocene establishment of vast tidal flats, the restriction of the mangrove forest composition to environmentally robust species and the shift of freshwater swamps to seasonal wetlands reflect aridification.

The results presented here quantify Holocene coastal landscape dynamics in the eastern Kimberley region for the first time. Our record shows that the timing and rate of coastal ecosystem development in north-west Australia were different from other regions in tropical Australia. Our record provides further evidence for increased moisture availability in the area during the early Holocene with a subsequent late Holocene shift to more arid conditions.

\section{Supporting Information}

Additional supporting information can be found in the online version of this article:

Table S1 Summary of all surface sediment samples, their environmental context and pollen sums. 
Acknowledgements. U.P. acknowledges the German Academic Exchange Service (DAAD) for funding her Postdoctoral Fellowship at the ANU. Luke Bentley from the Department of the Environment and Conservation (DEC) in Kununurra is thanked for his help during this project. Fieldwork was carried out with the DEC Regulation 4 Authority Permit CE003064 and with financial support from the Kimberley Foundation of Australia. DH's work was supported by the Australian Research Council (grant DP110105419). The comments of one anonymous reviewer and Peter Kershaw improved the manuscript greatly.

Abbreviations. EM 3, end-member 3; ENSO, El Niño-Southern Oscillation.

\section{References}

Abram NJ, McGregor HV, Gagan MK, et al. 2009. Oscillations in the southern extent of the Indo-Pacific Warm Pool during the midHolocene. Quaternary Science Reviews 28: 2794-2803.

Ball MC. 1988. Salinity tolerance in the mangroves Aegiceras corniculatum and Avicennia marina. I. Water use in relation to growth, carbon partitioning, and salt balance. Functional Plant Biology 15: 447-464.

Beard JS. 1979. Vegetation survey of Western Australia: Kimberley; Explanatory notes to sheet 1 The vegetation of the Kimberley area. The University of Western Australia: Nedlands

Bennett K. 2005. Documentation for Psimpoll 4.25 and Pscomb 1.03: C Programs for Plotting Pollen Diagrams and Analysing Pollen Data. Department of Earth Sciences, University of Uppsala: Uppsala.

Bennett KD, Willis K. 2001. Pollen. In Tracking Environmental Change Using Lake Sediments: Terrestrial, Algal and Siliceous Indicators, Smol JP, Birks HJB, Last WM (eds). Kluwer Academic Publishers: Dordrecht; 5-32.

Berkeley A, Perry CT, Smithers SG, et al. 2009. Foraminiferal biofacies across mangrove-mudflat environments at Cocoa Creek, north Queensland, Australia. Marine Geology 263: 64-86.

Blott SJ, Pye K. 2001. Gradistat: A grain size distribution and statistics package for the analysis of unconsolidated sediments. Earth Surface Processes and Landforms 26: 1237-1248.

Bowman DMJS, Brown GK, Braby MF, et al. 2010. Biogeography of the Australian monsoon tropics. Journal of Biogeography 37: 201216.

Bureau of Meterology. 2011. Climate Reports.

CALM. 1998. Lower Ord Ramsar site: draft management report. Department of Conservation \& Land Management: Kununurra, WA; 68.

CALM. 2008. Ord River and Parry Lagoons Nature Reserves Draft Management Plan. Department of the Environment and Conservation: Perth; 16.

Chappell J. 1993. Contrasting Holocene sedimentary geologies of lower Daly River, northern Australia, and lower Sepik-Ramu, Papua New Guinea. Sedimentary Geology 83: 339-358.

Clark RL, Guppy JC. 1988. A transition from mangrove forest to freshwater wetland in the monsoon tropics of Australia. Journal of Biogeography 15: 665-684.

Clarke JDA, Bone Y, Cann JH, et al. 2001. Post-glacial biota from the inner part of southwest Joseph Bonaparte Gulf. Australian Journal of Earth Sciences 48: 63-79.

Clarke JDA, Ringis J. 2000. Late Quaternary stratigraphy and sedimentology of the inner part of southwest Joseph Bonaparte Gulf. Australian Journal of Earth Sciences 47: 715-732.

Coleman JM, Wright LD. 1978. Sedimentation in an Arid Macrotidal Alluvial River System: Ord River, Western Australia. Journal of Geology 86: 621-642.

Crowley G, Gardener M, Marrinan M. 2007. Tropical Savannas Fire Response Database. Tropical Savannas Cooperative Research Centre: Darwin.

Crowley GM. 1996. Late Quaternary mangrove distribution in northern. Australia; Australian: Systematic Botany, 9: 219-225.

Crowley GM, Anderson P, Kershaw AP, et al. 1990. Palynology of a Holocene marine transgressive sequence, lower Mulgrave River valley, north-east Queensland. Australian Journal of Ecology 15: 231-240.

Crowley GM, Gagan MK. 1995. Holocene evolution of coastal wetlands in wet-tropical northeastern Australia. Holocene 5: 385399.

Crowley GM, Grindrod J, Kershaw AP. 1994. Modern pollen deposition in the tropical lowlands of northeast Queensland, Australia. Review of Palaeobotany and Palynology 83: 299-327.

Denniston RF, Wyrwoll K-H, Polyak VJ, et al. 2013. A stalagmite record of Holocene Indonesian-Australian summer monsoon variability from the Australian tropics. Quaternary Science Reviews 78: 155-168.

Department of Defence. 2005. Erskine, Western Australia, 1:100000.

Duke N. 2006. Australia's Mangroves: the Authoritative Guide to Australia's Mangrove Plants. University of Queensland: Brisbane.

Dyer RM. 2001. Fire and Vegetation Management in Pasture Lands of the Victoria River District, Northern Territory. School of Land and Food Sciences University of Queensland: Brisbane, p. 191.

Ellison JC. 2008. Long-term retrospection on mangrove development using sediment cores and pollen analysis: a review. Aquatic Botany 89: 93-104.

Fallon SJ, Fifield LK, Chappell JM. 2010. The next chapter in radiocarbon dating at the Australian National University: Status report on the single stage AMS. Nuclear Instruments and Methods in Physics Research. Section B: Beam Interactions with Materials and Atoms 268: 898-901.

Griffiths ML, Drysdale RN, Gagan MK, et al. 2010. Evidence for Holocene changes in Australian-Indonesian monsoon rainfall from stalagmite trace element and stable isotope ratios. Earth and Planetary Sciences Letters 292: 27-38.

Grindrod J. 1988. The palynology of Holocene mangrove and saltmarsh sediments, particularly in Northern Australia. Review of Palaeobotany and Palynology 55: 229-245.

Grindrod J, Moss P, van der Kaars S. 1999. Late Quaternary cycles of mangrove development and decline on the north Australian continental shelf. Journal of Quaternary Science 14: 465-470.

Grindrod J, Moss P, van der Kaars S. 2002. Late Quaternary mangrove pollen records from continental shelf and ocean cores in the north Australian-Indonesian region. In Bridging Wallace's Line: The environmental and cultural history and dynamics of the SEAsian-Australian Region, Kershaw P, David B, Tapper N, Penny D et al. (eds). Catena: Reiskirchen; 119-146.

Grindrod J, Rhodes EG. 1984. Holocene sea-level history of a tropical estuary: Missionary Bay, north Queensland. In Coastal Geomorphology in Australia, Thom BG (ed.). Academic Press: North Ryde, NSW; 151-178.

Haslett J, Parnell A. 2008. A simple monotone process with application to radiocarbon-dated depth chronologies. Journal of the Royal Statistical Society. Series C (Applied Statistics) 57: 399 418.

Heslop D, De Schepper S, Proske U. 2011. Diagnosing the uncertainty of taxa relative abundances derived from count data. Marine Micropaleontology 79: 114-120.

Huang T-C. 1972. Pollen Flora of Taiwan. National Taiwan University Botany Dept. Press.

Jaffé R, Ding Y, Niggemann J, et al. 2013. Global charcoal mobilization from soils via dissolution and riverine transport to the Oceans. Science 340: 345-347.

Jennings JN. 1975. Desert dunes and estuarine fill in the Fitzroy estuary (north-western Australia). Catena 2: 215-262.

Kershaw AP, Clark JS, Gill AM. 2002. A history of fire in Australia. In Flammable Australia: the Fire Regimes and Biodiversity of a Continent, Bradstock R, Williams J, Gill AM (eds). Cambridge University Press: Cambridge; 3-25.

Lambeck K. 2002. Sea level change from mid Holocene to Recent time: an Australian example with global implications. Geodynamics Series 29: 33-50.

Lambeck K, Nakada M. 1990. Late Pleistocene and Holocene sea-level change along the Australian coast. Palaeogeography, Palaeoclimatology, Palaeoecology 89: 143-176.

Lees BG. 1992. The development of a chenier sequence on the Victoria Delta, Joseph Bonaparte Gulf, northern Australia. Marine Geology 103: 215-224. 
Lessa G, Masselink G. 2006. Evidence of a mid-Holocene sea level highstand from the sedimentary record of a macrotidal barrier and paleoestuary system in northwestern Australia. Journal of Coastal Research 22: 100-112.

Lewis SE, Sloss CR, Murray-Wallace CV, et al. 2013. Post-glacial sea-level changes around the Australian margin: a review. Quaternary Science Reviews 74: 115-138.

Li Z, Zhang Z, Li J, et al. 2008. Pollen distribution in surface sediments of a mangrove system, Yingluo Bay, Guangxi, China. Review of Palaeobotany and Palynology 152: 21-31.

Mao L, Batten DJ, Fujiki T, et al. 2012. Key to mangrove pollen and spores of southern China: an aid to palynological interpretation of Quaternary deposits in the South China Sea. Review of Palaeobotany and Palynology 176-177: 41-67.

Mao L, Zhang Y, Bi H. 2006. Modern pollen deposits in coastal mangrove swamps from northern Hainan Island, China. Journal of Coastal Research 22: 1423-1436.

McCormac FG, Hogg AG, Blackwell PG, et al. 2004. SHCal04 Southern Hemisphere Calibration 0-11.0 cal kyr BP. Radiocarbon 46: 1087-1092.

McGowan H, Marx S, Moss P, et al. 2012. Evidence of ENSO mega-drought triggered collapse of prehistory Aboriginal society in northwest Australia. Geophysical Research Letters 39: L22702.

Michie MG. 1987. Distribution of foraminifera in a macrotidal tropical estuary: Port Darwin, Northern Territory of Australia. Australian Journal of Marine and Freshwater Research 38: 249259.

Mulrennan ME, Woodroffe CD. 1998. Holocene development of the lower Mary River plains, Northern Territory, Australia. Holocene 8: $565-579$.

Myerscough PJ, Whelan RJ, Bradstock RA. 2001. Ecology of Proteaceae with special reference to the Sydney region. Cunninghamia 6: $951-1015$.

Parnell AC, Buck CE, Doan TK. 2011. A review of statistical chronology models for high-resolution, proxy-based Holocene palaeoenvironmental reconstruction. Quaternary Science Reviews 30: 2948-2960.

Reeves JM, Bostock HC, Ayliffe LK, et al. 2013. Palaeoenvironmental change in tropical Australasia over the last 30,000 years - a synthesis by the OZ-INTIMATE group. Quaternary Science Reviews 74: 97-114.

Rowe C. 2005. A Holocene History of Vegetation Change in the Western Torres Strait Region. School of Geography and Environmental Science, Monash University: Clayton, Queensland.

Rowe C. 2007. Vegetation change following mid-Holocene marine transgression of the Torres Strait shelf: a record from the island of Mua, northern Australia. Holocene 17: 927-937.

Ryżak M, Bieganowski A. 2011. Methodological aspects of determining soil particle-size distribution using the laser diffraction method. Journal of Plant Nutrition and Soil Science 174: 624633.

Semeniuk V. 1983. Mangrove distribution in Northwestern Australia in relationship to regional and local freshwater seepage. Vegetatio 53: $11-31$.

Shulmeister J. 1992. A Holocene pollen record from lowland tropical Australia. Holocene 2: 107-116.

Somboon JRP. 1990. Palynological study of mangrove and marine sediments of the Gulf of Thailand. Journal of Southeast Asian Earth Sciences 4: 85-97.

Stevenson J, Haberle S. 2005. Macro Charcoal Analysis: A Modified Technique Used by the Department of Archaeology and Natural History. Australian National University: Canberra; 9.

Thanikaimoni G. 1987. Mangrove Palynology. UNDP/UNESCO and Institut Français de Pondichéry; 100.
Thom BG, Wright LD, Coleman JM. 1975. Mangrove ecology and deltaic-estuarine geomorphology: Cambridge Gulf-Ord River, Western Australia. Journal of Ecology 63: 203-232.

Tomlinson PB. 1994. The Botany of Mangroves. Cambridge University Press: Cambridge.

van der Kaars S, Deckker PD, Gingele FX. 2006. A 100 000-year record of annual and seasonal rainfall and temperature for northwestern Australia based on a pollen record obtained offshore. Journal of Quaternary Science 21: 879-889.

WAH. 1998. FloraBase - the Western Australian Flora. Western Australian Herbarium, Department of Environment and Conservation

Wang P, Chappell J. 2001. Foraminifera as Holocene environmental indicators in the South Alligator River, northern Australia. Quaternary International 83-85: 47-62.

Wells AG. 1985. Grouping of tidal systems in the Northern Territory and the Kimberley Region of Western Australia on the presence/ absence of mangrove species. In Coasts and Tidal Wetlands of the Australian Monsoon Region, Bardsley KN, Davie JDS, Woodroffe CD (eds). Australian National University North Australia Research Unit: Darwin; 119-132.

Weltje G. 1997. End-member modelling of compositional data: Numerical-statistical algorithms for solving the explicit mixing problem. Mathematical Geology 29: 503-549.

Whitlock C, Larsen C. 2001. Charcoal as a fire proxy. In Tracking Environmental Change Using Lake Sediments: Terrestrial, Algal and Siliceous Indicators, Smol JP, Birks HJB, Last WM (eds). Kluwer Academic Publishers: Dordrecht; 75-98.

Wolanski E, Moore K, Spagnol S, et al. 2001. Rapid, human-induced siltation of the macro-tidal Ord River estuary, Western Australia. Estuarine Coastal and Shelf Science 53: 717-732.

Woodroffe CD. 1988. Changing mangrove and wetland habitats over the last 8000 years, northern Australia and South-East Asia. In Floodplains Research, Wade-Marshall D, Loveday P (eds). ANU North Australia Research Unit: Darwin; 1-33.

Woodroffe CD. 1993. Late Quaternary evolution of coastal and lowland riverine plains of South-East Asia and northern Australia: an overview. Sedimentary Geology 83: 163-175.

Woodroffe CD. 2000. Deltaic and estuarine environments and their Late Quaternary dynamics on the Sunda and Sahul shelves. Journal of Asian Earth Sciences 18: 393-413.

Woodroffe CD, Chappell JMA, Thom BG, et al. 1985a. Geomorphology of the South Alligator tidal river and plains, Northern Territory. In Coasts and Tidal Wetlands of the Australian Monsoon Region, Bardsley KN, Davie JDS, Woodroffe CD (eds). Australian National University North Australia Research Unit: Darwin; 3-15.

Woodroffe CD, Chappell JMA, Thom BG, et al. 1985b. Stratigraphy of the SouthAlligator tidal river and plains, Northern Territory. In Coasts and Tidal Wetlands of the Australian Monsoon Region, Bardsley KN, Davie JDS, Woodroffe CD (eds). Australian National University North Australia Research Unit: Darwin; 17-30.

Woodroffe CD, Grindrod J. 1991. Mangrove biogeography: the role of Quaternary environmental and sea-level change. Journal of Biogeography 18: 479-492.

Woodroffe CD, Thom BG, Chappell J. 1985c. Development of widespread mangrove swamps in mid-Holocene times in northern Australia. Nature 317: 711-713.

Woodroffe SA. 2009. Testing models of mid to Late Holocene sealevel change, North Queensland, Australia. Quaternary Science Reviews 28: 2474-2488.

Wright LD, Coleman JM, Thom BG. 1973. Processes of channel development in a high-tide-range environment: Cambridge GulfOrd River Delta, Western Australia. Journal of Geology 81: 15-41.

Yokoyama Y, Lambeck K, Deckker PD, et al. 2000. Timing of the Last Glacial Maximum from observed sea-level minima. Nature 406: $713-716$. 